Pobrane z czasopisma Annales H - Oeconomia http://oeconomia.annales.umcs.pl Data: 26/04/2023 04:25:45

DOI:10.17951/h.2017.51.6.301

\begin{tabular}{lc}
\hline & A N N A L E S \\
UNIVERSITATIS MARIAE CURIE-SKŁODOWSKA \\
LUBLIN - POLONIA \\
SOL. LI, 6 \\
SECTIO H
\end{tabular}

Wrocław University of Economics. Faculty of Economic Sciences

MAREK PAUKA, MARTYNA ŻYŁA

marek.pauka@ue.wroc.pl, martyna.zyla@ue.wroc.pl

\title{
Performance Signalling of Dividend Policy on the NewConnect Market
}

Sygnalizacja wyników finansowych w polityce dywidendowej na rynku NewConnect

Keywords: dividend changes; future earnings; Poland

Słowa kluczowe: zmiany dywidend; przyszłe wyniki finansowe; Polska

JEL Code: G17; G30; G35

\section{Introduction}

The aim of the paper is to examine whether changes in dividends may be treated as a signal from the managers about future performance of the company. We want to give evidence that in the market with high level of information asymmetry such as NewConnect (NC) payout policy may be interpreted as a tool for investors to build expectations about future financial results and therefore it could be a way of limitation the agency costs.

The NC market is characterised by relatively low entry barriers, although they were even lower prior to the radical change of regulation introduced in 2013. The companies issue shares usually under private placement with low dispersion of ownership on the basis of a modest information document. The market is open to relatively small companies with higher investment risks. Main owners usually remain on the management boards and institutional investors hardly appear on the market. 
The market coverage of analysts is small (Top Pick NewConnect stocks are exception to the rule). On such a market, companies that pay regular dividends are rare, so we suspected that those who opted to pay would have preferred to use dividend policy as a communication tool to reduce information asymmetry.

Our sample consists of 42 companies listed on the NC market between 2007 and 2016. The observation covered companies that had paid dividends for at least three consecutive years. A suspension of the payment for a maximum one year was allowed.

This paper makes contribution to the literature based on the unique hand-collected data. There is still a research gap in the Polish market dealing with dividend as a tool of signalling of future results of companies quoted on alternative investment market NewConnect which has not been the object of research before. For practitioners it is important that dividends changes do not act as predictors of future earnings.

\section{Background literature}

According to the agency theory [Jensen, Meckling, 1976; Kowerski, 2011], there are conflicts of interest between shareholders and managers of public companies. The dividend payout is against the needs of management and generates necessity to raise capital. Dividends treated as draining the company's free cash flow limit the investing activities of management board.

According to the signalling theory, dividend payouts diminish information asymmetry and are perceived as signals sent to the market by managers. They can be regarded as a way of delivering information about the current and future situation of a company. A change in the dividend may suggest the definite direction in which future earnings will head [Allen, Michaely, 2003]. A raise in dividend may be perceived as an announcement of improving future earnings. On the other hand, lowering dividend may suggest deterioration of a company's situation. Managers are reluctant to increase payouts, although they currently could manage it if they are not fully convinced about the sustainability of the company's profits in the future. It is due to fear of consequences resulting from a potential reduction in dividend in case they would not be able to keep payouts on a higher level continuously.

The beginning of deliberations on the signalling effect of dividends can be found in the work of Lintner [1956]. He claimed that a dividend increase is most likely not a signal of announcement for future earnings growth, but the permanent change of actual earnings. According to Lintner, dividend policy decisions are being made in such way that managers strive to reach a target payout ratio in the long term by gradually adjusting the dividend to this level through subsequent periods. Also, in case of only transitory shocks of profits dividends are being relatively smoothed instead of being aligned to the change in profits straight away. This stems from the conviction that managers want to avoid cutting dividends when a higher dividend payout is no longer justified. Miller and Modigliani [1961] emphasised the existence 
of the so-called information content of dividends. They believe that the change in a dividend payout ratio affects the change of the market price of the company. Miller and Modigliani argue that dividend payment can provide a signal about the current financial situation and development prospects of the entity. Because of this, issuers can change investors' expectations about the level of profits in subsequent periods.

Numerous empirical studies about signalling theory of dividends have been conducted (Table 1). The authors concentrated mainly on the accuracy of the assumption that a change in dividend payout is accompanied by a change of profits and/or of share price, but the hypothesis has not been explicitly confirmed so far.

Table 1. Literature review about signalling theory

\begin{tabular}{|c|c|c|c|}
\hline $\begin{array}{l}\text { Authors (year } \\
\text { of publication) }\end{array}$ & $\begin{array}{l}\text { Stock exchange, } \\
\text { sample size }\end{array}$ & Effects & Results \\
\hline Watts [1973] & $\begin{array}{l}310 \text { dividend- changing } \\
\text { companies from S\&P's } \\
\text { Compustat Annual } \\
\text { Investment tapes }\end{array}$ & $\begin{array}{l}\text { Impact on future } \\
\text { earnings }\end{array}$ & $\begin{array}{l}\text { Positive, but small relationship } \\
\text { between changes in size of future } \\
\text { earnings and unexpected changes in } \\
\text { the actual level of dividends }\end{array}$ \\
\hline Laub [1976] & $\begin{array}{l}30 \text { dividend-changing } \\
\text { companies }\end{array}$ & $\begin{array}{l}\text { Impact on future } \\
\text { earnings }\end{array}$ & $\begin{array}{l}\text { Results consistent with Watts's, but } \\
\text { stronger }\end{array}$ \\
\hline $\begin{array}{l}\text { Aharony, Swary } \\
\text { [1980] }\end{array}$ & $\begin{array}{l}\text { NYSE, } 149 \\
\text { dividend-changing } \\
\text { companies }\end{array}$ & $\begin{array}{l}\text { Dividends provide } \\
\text { additional information } \\
\text { about future prospects } \\
\text { than quarterly earnings } \\
\end{array}$ & $\begin{array}{l}\text { Support for the information content } \\
\text { of dividends }\end{array}$ \\
\hline Penman [1983] & $\begin{array}{l}246 \text { dividend-changing } \\
\text { companies from } \\
\text { Compustat Annual } \\
\text { Investment tapes }\end{array}$ & $\begin{array}{l}\text { If information con- } \\
\text { tained in earnings, } \\
\text { forecasts are reflected } \\
\text { in dividend decisions }\end{array}$ & $\begin{array}{l}\text { Information regarding managers' } \\
\text { expectation can be obtained from } \\
\text { earnings forecasts and dividend } \\
\text { announcements }\end{array}$ \\
\hline $\begin{array}{l}\text { Healy, Palepu } \\
\text { [1988] }\end{array}$ & $\begin{array}{l}\text { NYSE/AMEX, } 131 \\
\text { initiations } 172 \text { omissions }\end{array}$ & $\begin{array}{l}\text { Dividend relation with } \\
\text { earnings growth and } \\
\text { market reaction }\end{array}$ & $\begin{array}{l}\text { Earnings and abnormal price reaction } \\
\text { in line with dividend initiation or } \\
\text { omission }\end{array}$ \\
\hline $\begin{array}{l}\text { Cowan, Sant } \\
{[1994]}\end{array}$ & $\begin{array}{l}\text { NYSE/AMEX, } 381 \\
\text { companies/dividend } \\
\text { omissions }\end{array}$ & $\begin{array}{l}\text { Incfluence on compa- } \\
\text { nie's' valuation }\end{array}$ & $\begin{array}{l}\text { Increases in return variance, beta and } \\
\text { the dispersion of earnings forecasts } \\
\text { occur after dividend omissions }\end{array}$ \\
\hline $\begin{array}{l}\text { DeAngelo, } \\
\text { DeAngelo, } \\
\text { Skinner [1996] } \\
\end{array}$ & $\begin{array}{l}\text { NYSE, } 145 \text { dividend- } \\
\text { changing companies }\end{array}$ & $\begin{array}{l}\text { Dividends signal future } \\
\text { earnings }\end{array}$ & No support for dividend signalling \\
\hline $\begin{array}{l}\text { Benartzi, } \\
\text { Michaely, Thal- } \\
\text { er [1997] }\end{array}$ & $\begin{array}{l}\text { NYSE/AMEX, } 1,025 \\
\text { companies/7,186 events } \\
\text { of dividend changes; } 561 \\
\text { initiations, } 887 \text { omissions }\end{array}$ & $\begin{array}{l}\text { Dividends convey } \\
\text { information about } \\
\text { subsequent earnings }\end{array}$ & $\begin{array}{l}\text { Dividends adjust to the changes in } \\
\text { earnings. Strong earnings reaction } \\
\text { after initiation or omission }\end{array}$ \\
\hline $\begin{array}{l}\text { Grullon, } \\
\text { Michaely, } \\
\text { Swaminathan } \\
\text { [2002] }\end{array}$ & $\begin{array}{l}\text { NYSE/AMEX, 7,642 } \\
\text { dividend yields changes }\end{array}$ & $\begin{array}{l}\text { Relationship between } \\
\text { dividend changes and } \\
\text { systematic risk and } \\
\text { changes of life cycle }\end{array}$ & $\begin{array}{l}\text { Earnings fall (grow) when dividends } \\
\text { increase (decrease); systematic risk } \\
\text { declines after dividend increase } \\
\text { announcement; higher dividend } \\
\text { indicates company's maturity }\end{array}$ \\
\hline $\begin{array}{l}\text { Fuller, Thakor } \\
\text { [2002] }\end{array}$ & $\begin{array}{l}\text { NYSE/AMEX/NASDAQ, } \\
1,942 \text { companies/10,505 } \\
\text { dividend changes }\end{array}$ & $\begin{array}{l}\text { Cash-flow-distribution } \\
\text { motives of dividend } \\
\text { payments }\end{array}$ & $\begin{array}{l}\text { No evidence to support a concept that } \\
\text { dividend decisions help to determine } \\
\text { issuers with superior future earnings }\end{array}$ \\
\hline
\end{tabular}


Pobrane z czasopisma Annales H - Oeconomia http://oeconomia.annales.umcs.pl Data: 26/04/2023 04:25:45

MAREK PAUKA, MARTYNA ŻYŁA

\begin{tabular}{|l|l|l|l|}
\hline $\begin{array}{l}\text { Authors (year } \\
\text { of publication) }\end{array}$ & \multicolumn{1}{|c|}{$\begin{array}{c}\text { Stock exchange, } \\
\text { sample size }\end{array}$} & \multicolumn{1}{c|}{ Effects } & \multicolumn{1}{c|}{ Results } \\
\hline $\begin{array}{l}\text { Vieira, } \\
\text { Raposo [2007] }\end{array}$ & $\begin{array}{l}\text { Euronext Lisbon } \\
\text { (84 dividend-changing } \\
\text { companies), Euronext } \\
\text { Paris (93), LSE (524) }\end{array}$ & $\begin{array}{l}\text { Relation of dividend } \\
\text { announcements with } \\
\text { share price and future } \\
\text { profitability }\end{array}$ & $\begin{array}{l}\text { No significant support for dividend } \\
\text { signalling hypothesis for Portuguese } \\
\text { and French markets. Partial } \\
\text { confirmation for the UK market }\end{array}$ \\
\hline $\begin{array}{l}\text { Liljeblom, } \\
\text { Mollah, } \\
\text { Rotter [2015] }\end{array}$ & $\begin{array}{l}\text { Danish, Norwegian and } \\
\text { Swedish markets }\end{array}$ & $\begin{array}{l}\text { Dividends convey } \\
\text { information about } \\
\text { future earnings; } \\
\text { dividend stickiness }\end{array}$ & $\begin{array}{l}\text { Support both theories for the Swedish } \\
\text { market only }\end{array}$ \\
\hline $\begin{array}{l}\text { Gou, Maung, } \\
\text { Wilson [2015] }\end{array}$ & $\begin{array}{l}\text { NYSE/ NASDAQ, 36,742 } \\
\text { dividend changes }\end{array}$ & $\begin{array}{l}\text { Effect on changes in } \\
\text { forecasted earnings, } \\
\text { and how earnings } \\
\text { volatility influences } \\
\text { such an effect }\end{array}$ & $\begin{array}{l}\text { A positive relation between increases } \\
\text { of dividends and changes in future } \\
\text { earnings, but findings strongly } \\
\text { affected by earnings volatility }\end{array}$ \\
\hline
\end{tabular}

Source: own compilation.

Despite many papers contemplating on significance of dividend signalling on developed market, there is a research gap on the European alternative markets which are exposed to the risk of information asymmetry in particular.

\section{NewConnect as a market with strong asymmetry of information}

After regulation of multilateral trading facilities by EU law [Directive 2004/39/ EC], the Polish stock exchange has introduced its own alternative stock market NewConnect in 2007. NC has been dedicated to small- and medium-sized enterprises that are in the early development stage, thus, it follows the trend set by other markets in Europe.

The NC market considerably differs from the main stock market especially in regard to regulations imposed on the issuers. NewConnect is a non-regulated market and is the subject of direct supervision of the Warsaw Stock Exchange. Issuers should meet lower entry criteria and disclosure requirements and most of stocks are sold to investors under private placement. Considering ownership structure of issuers, in many cases the owners are simultaneously members of management boards of listed companies.

Another characteristic of NewConnect is a dominant role of individual investors. Although the involvement of institutional investors increases year by year, it is still negligible because of the poor market liquidity, low value of emissions (often do not exceed several million PLN) as well as poor information transparency.

Despite strengthening of the regulations, there is still greater information asymmetry occurring on NewConnect in comparison to the main market. One of the methods that helps to reduce agency costs being a result of monitoring companies' activities in order to reduce information asymmetry is dividend payout policy. This leads to the following hypothesis $\mathrm{H} 1$ : dividend changes positively influence the future financial performance measured by revenues, operating earnings and net income. 


\section{The data and research design}

A sample of 42 firms was selected from those listed on the NewConnect market. Each firm met the following criteria:

- the company paid dividend for at least three consecutive years or during at least four years it did not pay dividend in only one of the years,

- the company did not pay advance dividends,

- the company was present on the market long enough to publish the annual reports following the years in which it paid dividends.

The resulting sample contains 98 observations of dividend changes. The financial data was hand-collected from annual financial reports and the information about dividend proposals were collected based on current reports (disclosures after general meetings announcing dividend decisions).

To investigate our hypothesis, multiple regression is used. We choose dividend changes (dDIV) and financial ratios describing size (Assets, Equity), financial leverage (Debt) and profitability (ROA, ROE, ROAop) of companies as independent variables. The future performance is characterised by changes of revenues (dRev), operating earnings $(\mathrm{dOpE})$ and net income $(\mathrm{dNI})$ treated separately as a dependent variable in a regression model.

We determine changes in dividends and changes in financial performance as following:

1. Dividend changes dDIV is equal $\left(D_{n} / D_{n-1}\right)-1$, where $D_{n}$ is total dividend as a part of paid earnings achieved in year $n$, but paid in year $\mathrm{n}+1$.

2. As Variable (dependent variable) we use total revenues (Rev), operating earnings $(\mathrm{OpE})$ and net income $(\mathrm{NI})$ :

a) dVariable_n is equal (Variable ${ }_{n} /$ Variable $_{n-1}$ ) - 1 , where Variable ${ }_{n}$ refers to the year $n$ (year for which dividend was paid), i.e. dVariable_ $\mathrm{n}$ is a measure of changes in historical financial results, which were known before the dividend was proposed,

b) dVariable_n1 is equal (Variable ${ }_{n+1} /$ Variable $_{n}$ ) -1 , where Variable ${ }_{n+1}$ refers to year $n$ (year when dividend was paid), i.e. dVariable_n1 is a measure of future changes in financial results, which were not known during the time when the dividend was proposed and paid.

3. 'Assets' are value of assets in year $n$.

4. 'Equity' are value of equity in year $n$.

5. 'Debt' is a debt ratio equal to a percentage of total liabilities in assets in year $n$.

6. ROA, ROE, ROAop are return on assets (net income to assets), return on equity (net income to equity), operating return on assets (operating earnings to assets) in year $n$.

Our model is specified as:

dVariable_n $1=\beta_{0}+\beta_{1} * \mathrm{dDIV}+\beta_{2} *$ NI_n $+\beta_{3} *$ Debt $\_n+\beta_{4} * \operatorname{lnRev}+\beta_{5} *$ ROAop $+\varepsilon$ 
Pobrane z czasopisma Annales H - Oeconomia http://oeconomia.annales.umcs.pl

Data: 26/04/2023 04:25:45

\section{Empirical results and analysis}

In Table 2 we present descriptive statistics of variables. We can see that dividend changes are smaller than changes of net income or operating earnings and bigger than changes of revenues.

Table 2. Descriptive statistics

\begin{tabular}{|l|c|c|c|c|c|}
\hline Variables & Arithmetic mean & Median & Minimum & Maximum & St. dev. \\
\hline dDIV & $54.7 \%$ & $0.0 \%$ & $-86.4 \%$ & $1995.2 \%$ & $220.8 \%$ \\
\hline Rev_n & 62017.1 & 20004.0 & 2879.0 & 693492.0 & 126399.0 \\
\hline dRev_n & $24.9 \%$ & $5.9 \%$ & $-75.5 \%$ & $659.0 \%$ & $78.5 \%$ \\
\hline dRev_n1 & $21.7 \%$ & $7.2 \%$ & $-42.5 \%$ & $659.0 \%$ & $75.1 \%$ \\
\hline OpE_n & 2883.4 & 1516.0 & -3785.0 & 20756.0 & 4166.5 \\
\hline dOpE_n & $11.2 \%$ & $-3.8 \%$ & $-9900.0 \%$ & $3503.0 \%$ & $1119.6 \%$ \\
\hline dOpE_n1 & $-19.3 \%$ & $-6.7 \%$ & $-9900.0 \%$ & $3503.0 \%$ & $1109.8 \%$ \\
\hline NI_n & 2013.9 & 1196.0 & -4100.0 & 15847.0 & 3077.4 \\
\hline dNI_n & $80.1 \%$ & $-2.1 \%$ & $-2436.3 \%$ & $5366.7 \%$ & $655.6 \%$ \\
\hline dNI_n1 & $38.8 \%$ & $-11.5 \%$ & $-2436.3 \%$ & $5366.7 \%$ & $623.4 \%$ \\
\hline Assets_n & 48680.6 & 16841.0 & 2140.0 & 532299.0 & 107166.0 \\
\hline Equity_n & 31365.6 & 10057.5 & 1376.0 & 359885.0 & 75756.1 \\
\hline Debt_n & $39.1 \%$ & $36.7 \%$ & $1.4 \%$ & $77.8 \%$ & $19.8 \%$ \\
\hline ROE & $18.4 \%$ & $13.3 \%$ & $-45.7 \%$ & $93.2 \%$ & $22.4 \%$ \\
\hline ROAop & $13.1 \%$ & $8.6 \%$ & $-26.0 \%$ & $80.4 \%$ & $16.0 \%$ \\
\hline ROA & $10.0 \%$ & $7.3 \%$ & $-35.4 \%$ & $62.1 \%$ & $13.9 \%$ \\
\hline
\end{tabular}

Source: own calculations.

This stickiness of dividend is confirmed by the values of correlations between dividend changes and historical changes of performance (ending with_n) which is low. However, the correlation ratios referring to the future changes of performance (ending with_n1) are even lower (Table 3).

Table 3. Correlation of variables

\begin{tabular}{|c|c|c|c|c|c|c|c|}
\hline dDIV & dRev_n & dRev_n1 & dOpE_n & dOpE_n1 & dNI_n & dNI_n1 & \\
\hline \multirow[t]{7}{*}{1} & 0.3787 & 0.1344 & 0.2095 & 0.0115 & 0.3892 & -0.0088 & dDIV \\
\hline & 1 & -0.0150 & 0.1381 & 0.0616 & 0.8178 & -0.0623 & dRev $n$ \\
\hline & & 1 & -0.0750 & 0.1155 & -0.0246 & 0.8400 & dRev_n1 \\
\hline & & & 1 & 0.0153 & 0.1535 & 0.0169 & $\mathrm{dOpE} n$ \\
\hline & & & & 1 & -0.0115 & 0.1196 & $\mathrm{dOpE} n \mathrm{n} 1$ \\
\hline & & & & & 1 & -0.0244 & dNI_n \\
\hline & & & & & & 1 & dNI_n1 \\
\hline
\end{tabular}

Source: own calculations. 
Regression analysis shows that only future changes in revenues are significantly explained by the changes in dividends. It occurs that only positive dividend changes influence revenues significantly (however negative changes do not) what is shown in Table 4.

Table 4. Regression of dividend changes

\begin{tabular}{|c|c|c|c|c|c|c|c|c|}
\hline \multirow[t]{2}{*}{$\begin{array}{c}\text { Dependent } \\
\text { variable }(Y)\end{array}$} & \multicolumn{2}{|c|}{ dNI_n1 } & \multicolumn{2}{|c|}{ dOpE_n1 } & \multicolumn{2}{|c|}{ dRev_n1 } & \multicolumn{2}{|c|}{$\begin{array}{c}\text { dRev_n1 } \\
\text { (for positive dDIV) }\end{array}$} \\
\hline & Parameters & p-value & Parameters & p-value & Parameters & p-value & Parameters & p-value \\
\hline const & 4.20230 & 0.49 & -10.9014 & 0.3150 & 0.5446 & 0.4498 & 2.5206 & 0.1139 \\
\hline dDIV & 0.16250 & 0.62 & 0.1043 & 0.8598 & $0.0828 * *$ & 0.0371 & $0.1018^{*}$ & 0.0859 \\
\hline NI_n & 0.00001 & 0.98 & -0.0004 & 0.4152 & -0.00002 & 0.4520 & 0.0000 & 0.8004 \\
\hline Debt_n & 5.80820 & 0.12 & 6.7876 & 0.3033 & 0.5472 & 0.2126 & 0.7724 & 0.3433 \\
\hline $\ln R e v$ & -0.57820 & 0.39 & 0.8372 & 0.4811 & -0.0455 & 0.5649 & -0.2521 & 0.1455 \\
\hline ROAop & -2.89570 & 0.54 & 2.7786 & 0.7412 & -0.6354 & 0.2575 & -1.0628 & 0.2435 \\
\hline $\mathrm{R}^{2}$ & 0.03000 & & 0.0314 & & 0.0642 & & & 0.1097 \\
\hline
\end{tabular}

$*$ p-value under $0.1, * *$ p-value between 0.05 and 0.01

Source: own calculations.

The conclusions are similar to those shown by Benartzi, Michaely and Thaler [1997]. Again, it seems that dividends do not act as predictors of future earnings. Only with weak significance ( $\mathrm{p}$-value below 5\%) the changes in revenues are explained by the changes in dividends. It does not support our hypothesis. Similar conclusions were shown by Brycz and Pauka [2013] that the information power of dividends is not so strong to be the base for expectations for investors.

\section{Conclusions}

Our hypothesis is not proven based on the sample we collected from NewConnect. Although the market is not transparent and many characteristics justify presence of high level of information asymmetry, dividend may not be treated as a signal to raise expectations of investors about future financial results. Only changes of revenues with a very weak level of significance seem to be influenced by (only positive) changes of dividends. We show that dividend changes are more strongly correlated with historical changes in performance than with future ones. It could mean that managers decide to change dividends not in reaction to expected but to already obtained results. 


\section{Bibliography}

Aharony J., Swary I., Quarterly Dividend and Earnings Announcements and Stockholders'Returns: An Empirical Analysis, "Journal of Finance” 1980, Vol. 35(1),

DOI: https://doi.org/10.1111/j.1540-6261.1980.tb03466.x.

Allen F., Michaely R., Payout Policy, "Handbook of the Economics of Finance" 2003, Vol. 1A, DOI: https://doi.org/10.1016/S1574-0102(03)01011-2.

Benartzi S., Michaely R., Thaler R., Do Changes in Dividends Signal the Future or the Past?, "Journal of Finance" 1997, Vol. 52(3), DOI: https://doi.org/10.1111/j.1540-6261.1997.tb02723.x.

Brycz B., Pauka M., Dywidendy inicjalne jako sygnały o przyszłych wynikach na przykładzie spółek z GPW $w$ Warszawie, ,Zarządzanie i Finanse. Journal of Management and Finance” 2013, nr 2.

Cowan A.R., Sant R., Do Dividends Signal Earnings? The Case of Omitted Dividends, "Journal of Banking and Finance" 1994, Vol. 18(6).

DeAngelo H., DeAngelo L., Skinner D.J., Reversal of Fortune. Dividend Signaling and the Disappearance of Sustained Earnings Growth, "Journal of Financial Economics" 1996, Vol. 40,

DOI: https://doi.org/10.1016/0304-405X(95)00850-E.

Directive 2004/39/EC of the European Parliament and of the Council of 21 April 2004 on markets in financial instruments amending Council Directives 85/611/EEC and 93/6/EEC and Directive 2000/12/EC of the European Parliament and of the Council and repealing Council Directive 93/22/EEC.

Fuller K.P., Thakor A.V., Signaling, Free Cash Flow, and 'Nonmonotonic' Dividends, "Financial Review" 2002, Vol. 45(1), DOI: https://doi.org/10.2139/ssrn.343980.

Gou Y., Maung M., Wilson C., Dividend Changes and Future Profitability: The Role of Earnings Volatility, University of Saskatchewan, 2015.

Grullon G., Michaely M., Swaminathan B., Are Dividend Changes a Sign of Firm Maturity?, "Journal of Business" 2002, Vol. 75(3), DOI: https://doi.org/10.1086/339889.

Healy P.M., Palepu K.G., Earnings Information Conveyed by Dividend Initiations and Omissions, "Journal of Financial Economics" 1988, Vol. 21(2), DOI: https://doi.org/10.1016/0304-405X(88)90059-1.

Jensen M.C., Meckling W.H., Theory of the firm: Managerial Behaviour, Agency Costs and Ownership Structure, "Journal of Financial Economics" 1976, Vol. 3(4),

DOI: https://doi.org/10.1016/0304-405X(76)90026-X.

Kowerski M., Ekonomiczne uwarunkowania decyzji o wypłatach dywidend przez spółki publiczne, Konsorcjum Akademickie, Kraków 2011.

Laub P.M., On the Informational Content of Dividends, "Journal of Business" 1976, Vol. 49(1),

DOI: https://doi.org/10.1086/295811.

Liljeblom E., Mollah S., Rotter P., Do Dividends Signal Future Earnings in the Nordic Stock Markets?, "Review of Quantitative Finance and Accounting" 2015, Vol. 44(3),

DOI: https://doi.org/10.1007/s11156-013-0415-3.

Lintner J., Distribution of Incomes of Corporations among Dividends, Retained Earnings, and Taxes, "The American Economic Review" 1956, Vol. 46(2).

Miller M.H., Modigliani F., Dividend Policy, Growth, and Valuation of Shares, "Journal of Business” 1961, Vol. 34(4), DOI: https://doi.org/10.1086/294442.

Penman S.H., The Predictive Content of Earnings Forecasts and Dividends, "Journal of Finance" 1983, Vol. 38(4), DOI: https://doi.org/10.1111/j.1540-6261.1983.tb02290.x.

Vieira E., Raposo C., Signalling with Dividends? The Signalling Effects of Dividend Change Announcements: New Evidence from Europe, 2007.

Watts R., The Information Content of Dividends, "Journal of Business" 1973, Vol. 46(2), DOI: https://doi.org/10.1086/295525. 


\section{Sygnalizacja wyników finansowych w polityce dywidendowej na rynku NewConnect}

Celem artykułu jest sprawdzenie, czy zmiany w poziomie wypłacanych dywidend można uznać za informacje sygnalizujące zmiany w przyszłych wynikach finansowych (przychodach, zyskach operacyjnych, wyniku netto). Próba dotyczy 42 spółek notowanych na rynku NewConnect w latach 2007-2016, wypłacających regularnie dywidendę przez co najmniej 3 lata. Wykorzystując modele regresji liniowej, pokazano, że zmiany w poziomie wypłacanych dywidend pozytywnie wpływają na zmiany w przychodach, jednak w sposób nieistotny wyjaśniają zmiany wyników operacyjnych i wyników netto. Praca wypełnia lukę w badaniach empirycznych nad polskim rynkiem akcji - w szczególności po raz pierwszy zbadano funkcję sygnalizacyjną dywidend na rynku NewConnect, który charakteryzuje się wysokim poziomem asymetrii informacji.

\section{Performance Signalling of Dividend Policy on the NewConnect Market}

The aim of the paper was to give evidence whether changes of dividends could be considered as signals forecasting changes in future financial results. The sample consists of 42 companies listed on the NewConnect market in the years 2007-2016, paying regular dividends for at least 3 years. Using linear regression models, we show that dividend changes have a weak but positive effect on revenues changes, but they are insignificant when explaining changes in operating performance and net income. The paper fills a gap in empirical research on the Polish stock market, and especially the signalling function of dividends on NewConnect, which is characterised by a high degree of information asymmetry, has been examined for the first time. 